\title{
ÚLOHA POZEMKOVEJ DANE V LOKÁLNEJ POLITIKE
}

\section{ROLE OF LAND TAX IN LOCAL POLICY}

\section{ING. EVA BALÁŽOVÁ, PHD. ${ }^{1}$}

\author{
DOC. ING. VIERA PETRÁŠOVÁ, CSc. ${ }^{2}$ \\ ${ }^{1}$ Katedra verejnej správy $\mid{ }^{1}$ Department of Public Administration \\ ${ }^{2}$ Katedra regionalistiky a rozvoja vidieka ${ }^{2}$ Department of Regional and Rural Development \\ Fakulta európskych štúdií a regionálneho rozvoja Faculty of European Studies and Reg. Development \\ Slovenská polnohospodárska univerzita v Nitre $\mid$ Slovak University of Agriculture in Nitra \\ $\triangle$ Tr. A. Hlinku 2, 94976 Nitra, Slovak Republic \\ E-mail: eva.balazova@uniag.sk
}

\begin{abstract}
Anotácia
Pozemková dan̆ je oddávna ekonomickým nástrojom správcov územia. V súčasnom obdobi reštrukturalizácie pol’nohospodárstva a lesného hospodárstva spôsobuje táto daň problémy obhospodarovatel'om a uživatel'om lesnej a pol'nohospodárskej pôdy a neplní svoju historickú podstatu. Stagnujúci odbyt polnohospodárskych výrobkov nadvýrobou pol'nohospodárskej produkcie, nízky odbyt surového dreva a na druhej strane vplyvom klimatických zmien vznikajúce škody najmä záplavami alebo suchom spôsobujú obhospodarovatel'om pôdy vel'ké problémy znižujúce ich zisk. V stredoeurópskych regiónoch príjemcom pozemkovej dane je obec, ktorá v obdobi hospodárskej krízy ju využiva ako zdroj príjmov a nie ako motivačný nástroj pre obhospodarovanie pôdy v súlade s politikou životného prostredia a na základe poznatkov o ekosystémoch v regióne. Príspevok obsahuje návrh zmeny uplatnenia pozemkovej dane v politike samospráv na základe ovplyvnenia využitia pol'nohospodárskej a lesnej pôdy podl'a miestnych podmienok.
\end{abstract}

\section{Kl'účové slová}

lokálna politika, pol’nohospodárska pôda, lesná pôda, pozemková dă̌

\section{Annotation}

Land tax has always been an economical instrument for land managers. Nowadays, in the time of restructuring of agriculture and forestry the tax causes difficulties to the managers and users of agricultural and forest land as it does not fulfill its historical function. Stagnant market of agricultural products due to overproduction and low sales of green timber together with serious damages caused by climate changes bring on significant issues to the land managers mainly by decreasing their profit. In the Central European regions, the municipalities are beneficiaries of the land tax. Under the condition of economic recession the municipalities use the land tax as a source of income rather than as a motivation tool for land managers in order to encourage them to manage the land according to the environmental policy and based on the knowledge about ecosystems in the regions. The article offers suggestions for changes in land taxation within the municipal policy which are based on their influence on agricultural and forest land usage according to the local conditions.

\section{Key words}

regional policy, land tax, environmental policy 


\section{JEL classification: $R 51$}

\section{Úvod}

Slovensko ako tranzitívna krajina po roku 1989 budovala svoj inštitucionálny rámec pre trhovú ekonomiku a k tomu tiež príslušné legislatívne predpisy. Vstup do Európskej únie znamenal zvýraznil potrebu riešit' problematiku konkurencieschopnosti. Slovenská ekonomika doteraz, môžeme konštatovat', že konkuruje najmä nízkou cenou, ale najmä kvôli ponuke menej spracovaných výrobkov a nízkemu podielu sofistikovaných finálnych výrobkov. Tejto štruktúre ponuky zodpovedá nízka dynamika produktovej diferenciácie a inovácie. Podobná situácia vznikla aj pri hospodárení na pôde. Napriek nízkej cene pol'nohospodárskych produktov tieto boli vytlačené z trhu ponukou obchodných ret’azcov nakupujúcich vo vel'kom od pol’nohospodárskych odbytových družstiev v krajinách západnej Európy alebo lacnejšej zeleniny napr. z Pol'ska. Tieto obchodné kontrakty sú pre dodávatel'ov zo západnej Európy dohodnuté ako viacročné kontrakty naviazané na dodávky potravinárskeho spracovatel'ského priemyslu, ktorý u nás takmer úplne pre niektoré komodity upadol. Tým sa stalo, že nie sme v oblasti potravín bezpečnou krajinou ani čo sa týka množstva dopestovania základných potravín a ani čo sa týka kvality potravinových produktov. Predaj z dvora na podporu fariem sa začal rozbiehat' len pre 2-3 rokmi a politika podpory v pol’nohospodárstve je skôr zameraná na extenzívne ako intenzívne obhospodarovanie pôdy. V lesnom hospodárstve je situácia obdobná. Už 20 rokov sa vyváža surové drevo bez jeho spracovania na produkty s vyššou pridanou hodnotou. Podpora drevárskeho najmä nábytkárskeho priemyslu takmer neexistuje a podporuje sa skôr spracovanie menej kvalitnej drevnej hmoty ako surové drevo na energetické účely, na výrobu celulózy a papiera. Vládny program Drevo - surovina 21.storočia z roku 1999 nebol realizovaný.

Slovensko je hornatá krajina, kde lesná pôda (už takmer 42 \%) spolu s pol'nohospodárskou pôdou tvorí cez $90 \%$ povrchu krajiny. Okrem potenciálu pre cestovný ruch existuje aj možnost' sofistikovane využívat' toto prírodné bohatstvo bez ohl'adu nato, že pôda je vo vlastníctve rôznych osôb. Horské vidiecke oblasti, ale aj oblasti s vysokým podielom pol'nohospodárskej pôdy sú v súčasnosti na Slovensku najchudobnejšie. Potvrdzujú to aj výsledky nášho výskumu.

V súčasnom období, ked' dopady svetovej krízy sa prejavujú aj nedostatkom financií u miestnej samosprávy tak, pozemková daň ako miestna daň sa stáva z hladiska ekonomickej dimenzie komunálnej politiky dôležitou súčastou príjmov miest a obcí. Tento jav je historicky súčastou komunálnej politiky. Aj Európska charta miestnej samosprávy v čl. 9 ods. 3 uvádza: „Aspoň čast’ finančných zdrojov miestnych orgánov je odvodená z miestnych daní a poplatkov, ktorých výšku majú právo určovat'v medziach zákona tieto miestne orgány. "Nerovnováha medzi požiadavkami obcí na pozemkovú daň ako zdroja ich príjmu môže jej zdvihnutím sa odrazit’ aj vo zvýšení nájomného za pôdu, ktoré vstúpi do ceny pol'nohospodárskych, ale aj lesných produktov. Preto v období, ked' sa hladajú cesty zvyšovania konkurencieschopnosti je táto problematika vel'mi aktuálna, pretože hospodárenie na pôde znamená kultúrnu krajinu zásobujúcu obyvatel'ov pol’nohospodárskymi a drevárskymi obnovitel'nými produktmi s možnost'ou zvyšovania ich pridanej hodnoty produktov a služieb odvodených od pôdy. Dôvodom je pôsobenie diferenciálnej renty pri hospodárení na pôde (Cviková, 1993). Diferenciálna renta v SR zohráva významnú úlohu.

Ciel’om príspevku je zhodnotit’ návrh zmeny uplatnenia pozemkovej dane v politike samospráv na základe ovplyvnenia využitia pol’nohospodárskej a lesnej pôdy podla miestnych podmienok.

\section{Materiál a metódy}

Materiál pre analýzu súčasnej situácie problematiky a výskum sa získal z primárnych a sekundárnych zdrojov. Primárne zdroje sú tvorené údajmi získanými na základe vyplnenia empirických údajov v štruktúrovanom dotazníku pre obce a mestá v SR. Sekundárne zdroje sú získané z knižných publikácií od domácich a zahraničných autorov, internetových zdrojov zameraných na výsledky výskumu voblasti pozemkovej dane, z vládnych materiálov ku problematike pozemkovej dane, 
z odborných štúdií o daniach, zo všeobecne záväzných nariadení obcí a miest (VZN) a legislatívy SR a EÚ.

V rámci spracovania výskumu bola na zber údajov použitá metóda dotazníkového prieskumu. Jeho ciel'om bolo získanie podkladov pre analýzu situácie v oblasti pozemkovej dane za roky 2005 - 2011, najmä sa jednalo o nasledovné údaje: Výmera pôdy, Sadzba dane, Daňové výnosy, Bežné príjmy obce, podielové dane - príspevok štátu z daní fyzických osôb, počet obyvatel'ov obce (mesta). Respondentmi boli ekonómovia miest a obcí. Ukazovatele boli d’alej rozčlenené na urbanizované a neurbanizované oblasti.

\section{Výsledky a diskusia}

Zdaňovanie majetku a najmä nehnutel'ného patrí historicky $\mathrm{k}$ najstarším druhom daní. Pôda je vzhl'adom k ponuke absolútne obmedzená a je neobnovitel'ná. Pôdy sa líšia úrodnost'ou, výhodnost'ou polohy, vzdialenost'ou ku spracovatel'skému priemyslu. Zmenou dopytu po pôde sa mení jej cena a renta. Pôda vystupuje ako súkromný a verejný statok. Je teda nielen zdrojom príjmov pre vlastníka a plní pre neho sociálnu funkciu, ale zároveň je pre spoločnost' verejný statok, ktorý plní tak ekologické ako aj environmentálne funkcie (Obr. 1 ).

\section{Obr. 1: Pôda ako súkromný a verejný statok}

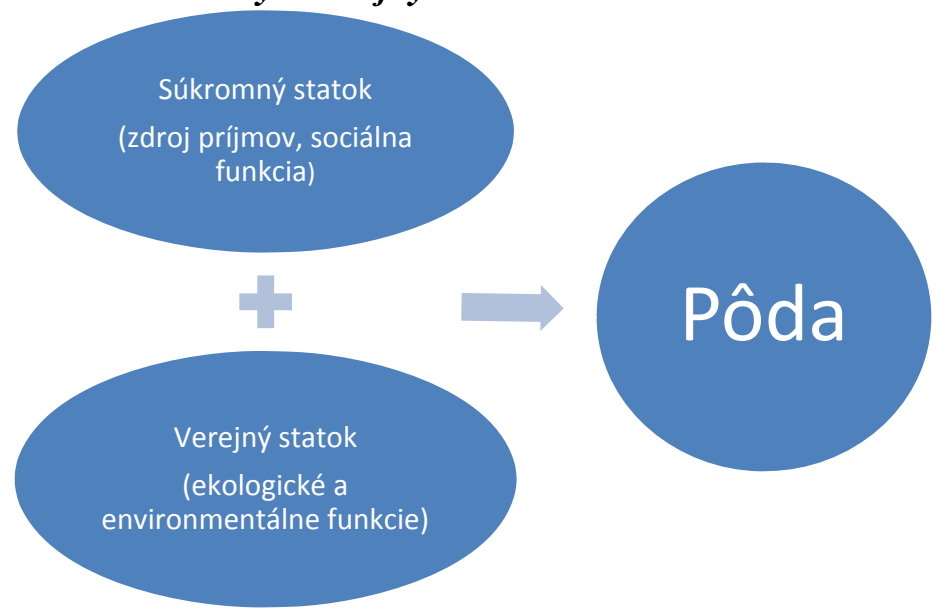

Zdroj: Vlastné spracovanie

Zdaňovanie majetku sa realizuje $\mathrm{v}$ krajinách sveta na základe uplatnenia princípu úžitku. Štát uplatňuje daň, ale na druhej strane zároveň zvyšuje hodnotu majetku tým, že sa tam v mieste výskytu nehnutel'ností poskytujú verejné služby, buduje sa infraštruktúra a iné čo zvyšuje hodnotu nehnutel'ností. Platca dane teda svojim poplatkom „priamo“ prispieva na „svoj“ majetok a zvyšujú jeho hodnotu. V tomto prípade sa môže v stanovení hodnoty dane odrazit' súvislost's vel'kost'ou mesta a obce, využívaním infraštruktúry. 


\section{Obr. 2: Pozemková daň odvodená na princípe úžitku}

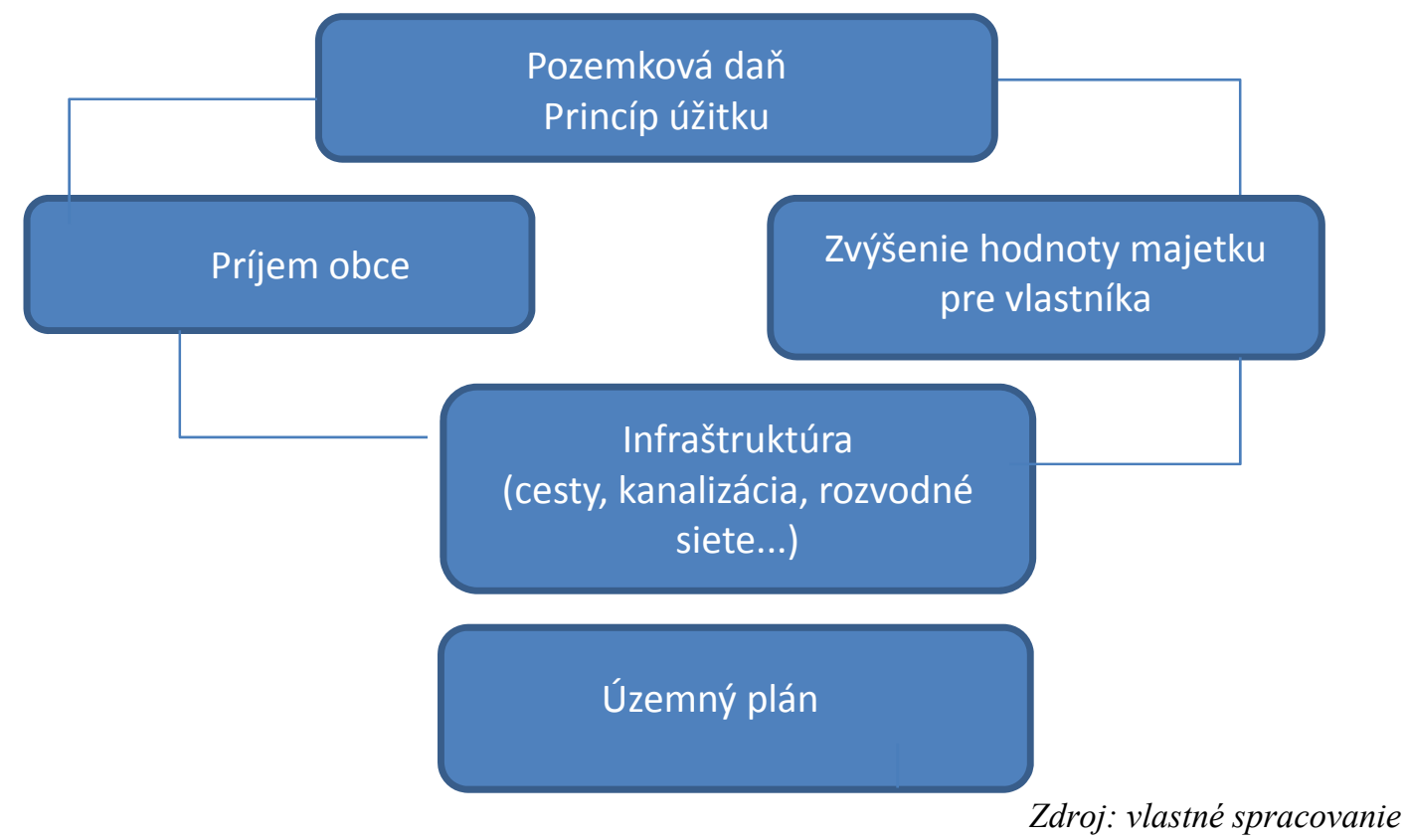

Pri presadzovaní výraznejšieho vplyvu spoločenskej regulácie sa uplatňuje princíp schopnosti daňovej úhrady. V tomto prípade sa hodnota dane odvíja od čistej hodnoty majetku. V tomto prípade sa regulujú rozdielne hodnoty v nerovnomernom rozdelení spotreby a bohatství (Lisý a kol., 1999). Spoločnost' tak vstupuje do stanovenia hodnoty daní, že rieši tieto problémy osobitne. Je to príklad najmä pri progresívnej forme zdanenia či uplatňovaní znížených sadzieb daní.

Zdanenie pozemkov má okrem iného vplývat na trh s pôdou obmedzovaním špekulácií pri obchodovaní s pôdou. V súvislosti s touto daňou si zasluhujú pozornost' prvky redistribúcie, nakol'ko pôda je zdrojom zisku. Daňová redistribúcia je však obmedzená vzhl'adom na súkromné vlastníctvo pôdy a budov.

Predmetom pozemkovej dane v podstate sú:

- majetok využívaný na pol'nohospodárske a lesnícke účely

- budovy a stavby

- pozemky a budovy určené na priemyselné účely.

Majetok na pol’nohospodárske a lesnícke účely je pomerne široký pojem a zahŕňa pôdu, hospodárske a obytné budovy, stroje, živý inventár ako aj obratové prostriedky.

Zdaňovanie pôdy a budov je vykonávané rôznymi spôsobmi. Môžeme vymenovat' štyri formy: v závislosti od hodnoty, od výšky nadobudnutého príjmu, od prenesenia sa ich hodnoty alebo vlastníctva, ako aj od prírastku hodnoty vplyvom priestorového usporiadania. Podl'a tohto princípu dane delíme na:

- dane z pozemku

- dane z príjmov z pozemku

- dane z nadobudnutia pozemku a budov

- dane z prírastku hodnoty pozemku a budov.

V prípade predmetu skúmania $\mathrm{v}$ príspevku ide o dane z pozemku. Štátna pôdna politika zasahuje do ochrany pôdy. Ochranu kvality a kvantity pôdy rieši zákonmi. Na druhej strane zasahuje svojim spôsobom aj do cenovej politiky, ked' obce môžu využívat' pre výpočet miestnej pozemkovej dane štátom „určené“ ceny. Pozemková daň má lokálny charakter a vo väčšine prípadov ju vyberajú 
samosprávy a slúži len pre ich účely. Samosprávy v prípade „určenej“ ceny pol’nohospodárskej a lesnej pôdy nemôžu využívat' vlastné rozhodnutia z územného plánu o využití územia.

Na Slovensku došlo od roku 2005 k decentralizácii daňovej sústavy, čím sa posilnili kompetencie v otázkach stanovenia a výberu daní mestám a obciam. K miestnym daniam fakultatívneho typu patrí daň z nehnutel'ností, ktorú stanovujú mestá (obce) v medziach zákona na všetky typy nehnutel'ného majetku, t.j. pozemky a stavby.

\section{Obr.3: Vývoj priemerných sadzieb daní z nehnutel'ností po roku 2004 v SR}

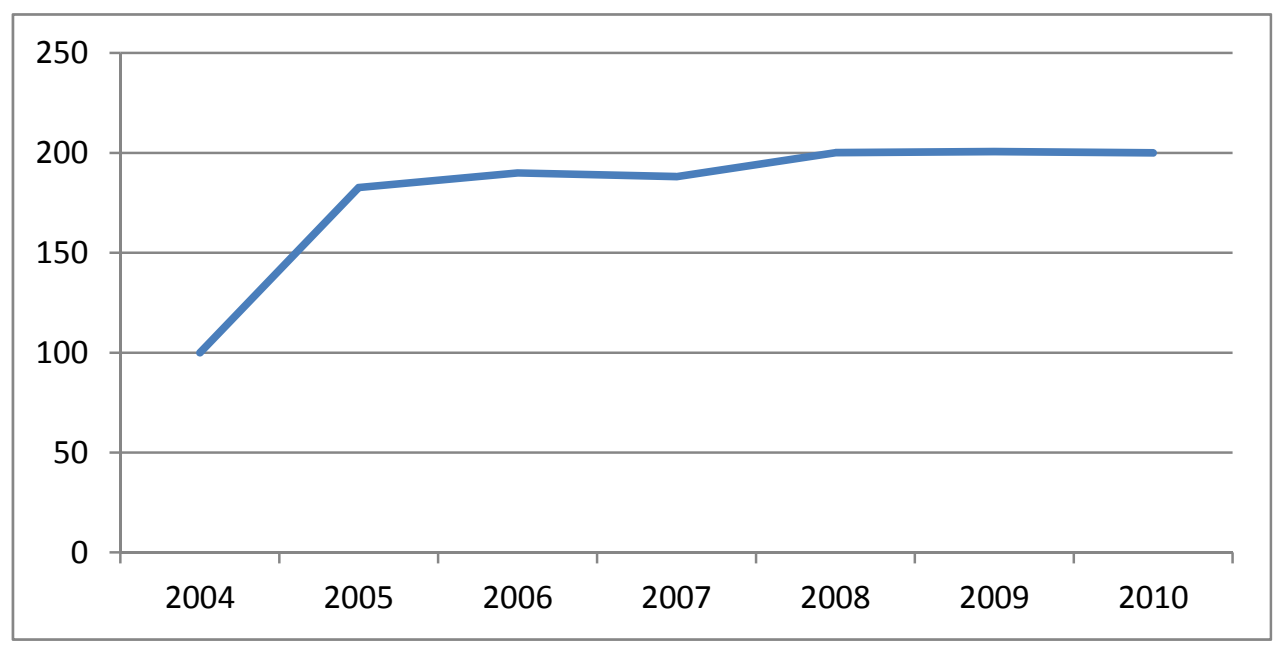

Zdroj: ŠÚ SR, vlastné spracovanie

Na Slovensku je doteraz kvantifikácia dane z nehnutel’nosti založená na ploche, nie na trhovej hodnote nehnutel'nosti alebo na inej hodnote pozemkov vyplývajúcej z ochrany pôdy (Barsvary, 1998). Tento nedostatok v kvantifikácii pozemkovej dane a to exaktne kvantifikovat' trhovú hodnotu ekologických a environmentálnych funkcií pôdy, ktoré bezplatne využíva verejnost' a zahrnút' ju do ekonomických výpočtov je dôvodom prečo v poslednom období sa dvíha nevôl'a voči jej uplatňovaniu pre vlastníkov pôdy. V minulosti uplatňované národné dotácie takmer neexistujú. Tieto boli v minulom období, môžeme povedat', akoby platbou spoločnosti vlastníkom pôdy (Pavel a kol., 2009). V súčasnom období preto vlastník pocit’uje akoby „trest“ za vlastníctvo pôdy, ktorej užívanie (vlastník má obmedzené právo uživania všetkých úžitkov) je v rukách najmä spoločnosti.

Tab. 1: Výhody a nevýhody súčasného systému pri pozemkovej dani z pol’nohospodárskej a lesnej pôdy

\begin{tabular}{|l|l|l|}
\hline $\begin{array}{l}\text { Výhoda takto určenej dane } \mathrm{z} \\
\text { nehnutel'nosti }\end{array}$ & Nevýhoda takto určenej dane z nehnutel'nosti \\
\hline Nízka administratívna náročnost' & $\begin{array}{l}\text { Nie je viazaná na individuálnu podnikatel'skú schopnost' } \\
\text { vlastníka uhradit' ju }\end{array}$ \\
\hline Progresivita dane & $\begin{array}{l}\text { Nie je viazaná na platobnú schopnost' k vlastnenému } \\
\text { pozemkovému vlastníctvu }\end{array}$ \\
\hline Zdroj lokálnych príjmov & Je politicky citlivá na miestnej úrovni \\
\hline $\begin{array}{l}\text { Nezávislost' od daňového systému } \\
\text { štátu }\end{array}$ & Nie je citlivá na ekologické a environmentálne funkcie pôdy \\
\hline
\end{tabular}

Zdroj: Vlastné spracovanie

Na druhej strane je tu obec, ktorej príjmy neustále klesajú a to aj na výkony prenesených kompetencií, ktoré obec by mala zabezpečovat' na základe príjmov resp. transferov od štátu (Nižňanský, 2009). Na obrázku 3 sme na základe údajov obcí z dotazníka ekonomických údajov $\mathrm{k}$ dani $\mathrm{z}$ pozemkov znázornili klesajúci trend príspevku štátu obciam. Výrazný pokles sa prejavil po vypuknutí svetovej 
ekonomickej globálnej krízy po roku 2009. Situácia v príjmoch obcí odvodených najmä z daní fyzických osôb sa nezlepšuje. V SR neklesá nezamestnanost', čím nerastú ani príjmy pre obce z daní fyzických osôb.

Obr. 3: Vývoj príspevku štátu obciam

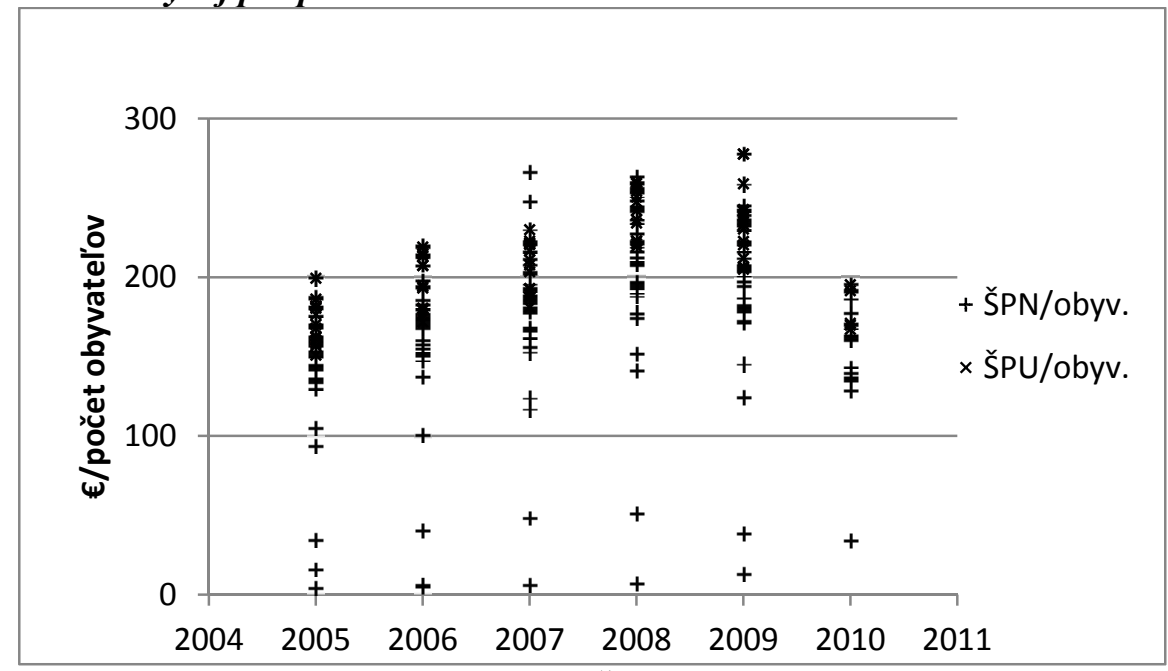

Zdroj: Vlastné spracovanie (ŠPN - štátny príspevok neurbanizované oblasti, ŠPU - štátny príspevok urbanizované oblasti)

Výsledky analýzy potvrdzujú politiku obcí. Zvyšovanie príjmu obcí z miestnych daní nie je pre miestnych politikov prioritné. Obava pred obyvatel'mi kvôli zvoleniu opät' do zastupitel'stva samosprávy núti miestnych politikov vyvíjat’ tlak na zvyšovanie najmä príjmov regulovaných štátom. Významný vplyv na daň z nehnutel'nosti má hodnota príspevku od štátu. Od reformy financovania obcí v roku 2005 môžeme konštatovat, že príspevok štátu na obyvatel'a sa pohyboval v rokoch 2005-2010 od 120 do $280 €$ /obyvatel'a (Obr.3). Po vzniku svetovej finančnej krízy v rokoch 2009-2010 zaznamenávame klesajúci trend v hodnote príspevku štátu. Klesanie hodnoty príspevku sa prejavilo tak ako u urbanizovaných obcí tak aj u neurbanizovaných obcí. $Z$ analýzy vývoja je zrejmé, že vplyv urbanizácie je významný pre získanie štátneho príspevku. Obce v neurbanizovaných územiach dosahujú hodnotu štátneho príspevku v intervale od 10 do $270 €$ /obyvatel’a (Obr.3).Obce v urbanizovaných obciach majú štátny príspevok v hodnote od 120 do $280 €$ /obyv.(Obr. 3).

\section{Obr. 4: Vývoj bežného príjmu obcí}

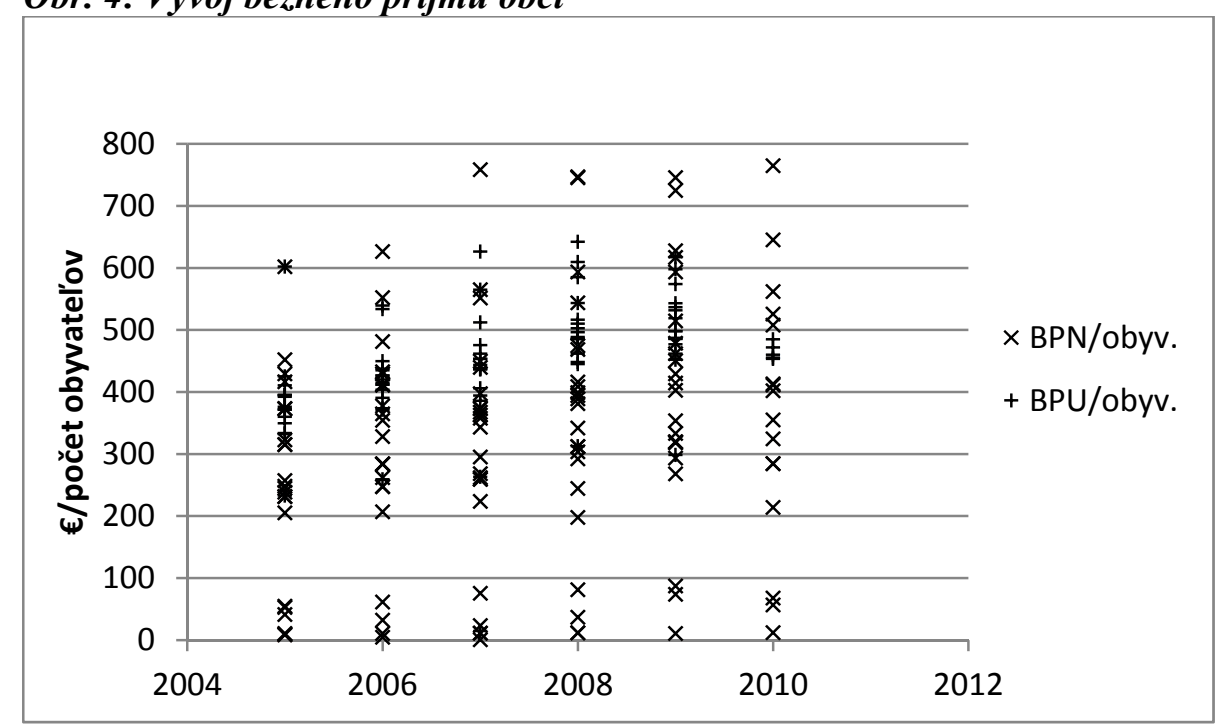

Zdroj: Vlastné spracovanie (BPN-štátny príspevok neurbanizované oblasti, BPU - štátny príspevok urbanizované oblasti) 
Významný vplyv na daň z nehnutel’nosti má bežný príjem obce (Obr. 4). Pri analýze obcí rozdelených na urbanizované a neurbanizované vidíme, že tak ako $\mathrm{v}$ prípade štátneho príspevku aj v tomto prípade neurbanizované obce majú nižšie príjmy. Existujú obce v neurbanizovaných regiónoch, ktoré nemajú žiadne príjmy, ale na druhej strane sú obce, ktoré dokážu získat' viac prostriedkov ako v urbanizovaných obciach. Je to až $790 €$ /obyvatel'a (Obr. 4). Vplyv času nie je významný tak ako je to $\mathrm{v}$ prípade príspevku štátu.

Súčasný systém zdaňovania pol’nohospodárskych a lesných pozemkov spôsobuje, že verejné využívanie pôdy prináša pre ich vlastníkov zvýšenie rizík ich poškodenia (krádeže úrody, požiare, znečistenie odpadmi pôdy, ale aj napr. vodných tokov, poškodzovanie pôdneho a vegetačného krytu až devastačného charakteru...). Na odstraňovanie dôsledkov zostáva vlastníkom len možnost' obrátit' sa najmä na políciu a v tomto prípade musia dokazovat' majetkovú ujmu a zaplatit' si znalecký posudok. Orgány štátnej správy životného prostredia zaujíma spoločenská hodnota ujmy, ktorá je príjmom štátu. Daň z pozemkov sa stáva pre udržiavanie a rozvoj ekologických a environmentálnych funkcií pôdy, na ktorých by malo spoločnosti najviac záležat' d'alšou finančnou zát'ažou pre vlastníka pôdy.

\section{Záver}

Osobitost' majetkovej dane z pôdy spočíva $\mathrm{v}$ tom, že štát a aj samospráva, poskytujú aj také verejné služby, ktoré ovplyvňujú hodnotu majetku. Patrí sem napr. výstavba lokálnych a miestnych ciest, výstavba a oprava infraštruktúry obcí, budovanie a údržba vodovodov, kanalizácie, elektrickej siete, rozvodov plynu a podobne. To všetko môže zvyšovat' hodnotu pozemkov pol'nohospodárskej a lesnej pôdy. Okrem toho štát ústavou chráni súkromné vlastníctvo majetku a hospodárenie s ním. $\mathrm{Na}$ výmenu za tieto verejné služby a ochranu vlastníctva, musia vlastníci majetku platit' daň. Táto daň má lokálny charakter, nakol'ko infraštruktúrou sa vo všeobecnosti zaoberajú orgány samosprávy.

Majetok nie je len kategóriou ekonomickou, ale aj sociálno-politickou bez ohl'adu na typ politického zriadenia. Daň vychádzajúca nie z úžitku, ale z vplyvu spoločenskej regulácie vlastníctva majetku a hospodárenia s pôdou môže byt' stanovená progresívne. Doteraz však neuplatňujeme hl'adisko plnenie ekologických a environmentálnych funkcií pôdou a nezohl'adňujeme tiež kvalitu majetku. Najmä pri pol’nohospodárskej pôde sa vychádza z cien určených na kataster a nie sú zohl'adnené priamo kritériá kvality pôd.

Napriek tomu, že dane z pozemkov nedosahujú sadzbou vysokú hodnotu sú vel'kou zát’ažou pre obhospodarovatel'ov pôdy. V prípade pol'nohospodárskej pôdy zat’ažujú najmä najkvalitnejšie pôdy, ktoré v súčasnosti už nie sú tak výrazne dotované ako to bolo napr. pred dvadsiatimi rokmi. Obhospodarovatelia pôdy nemajú dostatok finančných prostriedkov na udržanie kvality pôdy a to najmä z dôvodu nezáujmu trhu o pol’nohospodárske výrobky. V prípade lesnej pôdy sú daňou zat’ažení aj vlastníci lesného majetku, ktorý nemá výnos aj 50-80 rokov. Vel'ké prírodné kalamity spôsobujú devastáciu celých území a vyžadujú si aktívnu pomoc celej spoločnosti. Daň z pozemkov preto stratila svoju historickú úlohu, kde vlastník ju platí spoločnosti za zvýšenie hodnoty jeho pozemkov zvýšením atraktivity pozemkov(výstavbou ciest, sietí vodovodov, kanalizácii...). Daň z nehnutel'nosti podl'a našich výsledkov závisí výrazne od finančnej situácie obcí. Je ekonomickým nástrojom obcí pre zvýšenie príjmu a neplní vôbec vo vzt'ahu k pôde environmentálne funkcie.

Pozemková daň je historickým ekonomickým nástrojom. Súčasná doba prináša novú situáciu v politike environmentálnej udržatel'nosti obhospodarovania pôdy. Potreba chránit' životné prostredie si vyžaduje zmenit' prístup k pozemkovej dani. Hospodárska kríza nemôže znamenat', že si spôsobíme zníženie starostlivosti o pôdu. Nový prístup musí znamenat' hl'adanie rovnováhy medzi ekologickým a ekonomickým pohladom na pôdu či štátu, ale aj obcí a prenesene aj ku pozemkovej dani. Táto nemôže byt' ohrozením pre obhospodarovatel'ov pôdy, ale opačne musí byt' príležitost'ou pre štát a obce podporit' environmentálnu udržatel'nost'. 


\section{Literatúra}

[1] BARSVARY J. Zdaňovanie pôdy v krajinách Európskej únie. Nitra: UVTIP, 1998. 14.s.

[2] CVIKOVÁ, Z. Pozemková daň a cena pôdy. Ekonomický časopis, 1993, 41, č. 7-8, s. 560-570

[3] LISÝ, J. a kol.: Dejiny ekonomických teórii (Vývoj ekonomickej vedy). Bratislava: Elita, 1999. ISBN 80-85323-93-1

[4] NIŽŇANSKÝ, V. Posilnenie finančnej autonómie miest a obcí. M.E.S.A.10 Centrum pre ekonomické a sociálne analýzy, 2009, Bratislava 46 s. ISBN: 978-80-89177-15-8.

[5] PAVEL, JíLKOVÁ, SLÁVIKOVÁ. Poplatkové systémy vobcich, rizika a priležitosti pre odpadové hospodárstvo. Praha: IEEP NF VŠE, 2009. s. 258. 